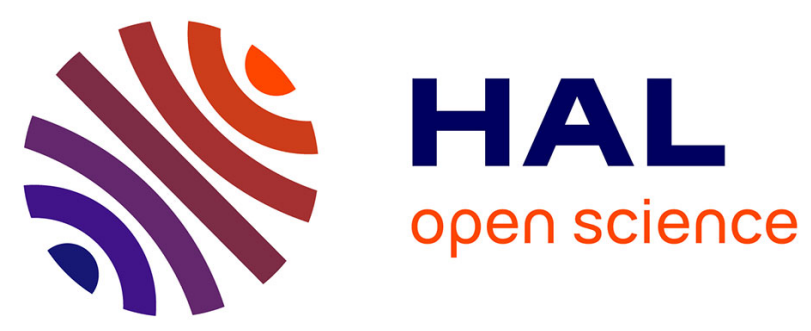

\title{
Biomarkers of CD4+ T-cell activation as risk factors for tuberculosis-associated immune reconstitution inflammatory syndrome.
}

\author{
Lisa A Chakrabarti, Céline Boucherie, Florence Bugault, Marie-Christine \\ Cumont, Caroline Roussillon, Guillaume Breton, Olivier Patey, Geneviève \\ Chêne, Laura Richert, Olivier Lortholary, et al.
}

\section{To cite this version:}

Lisa A Chakrabarti, Céline Boucherie, Florence Bugault, Marie-Christine Cumont, Caroline Roussillon, et al.. Biomarkers of CD4+ T-cell activation as risk factors for tuberculosis-associated immune reconstitution inflammatory syndrome.. AIDS. Official journal of the international AIDS Society, 2014, 28 (11), pp.1593-602. 10.1097/QAD.0000000000000311 . pasteur-01092056

\section{HAL Id: pasteur-01092056}

\section{https://hal-pasteur.archives-ouvertes.fr/pasteur-01092056}

Submitted on 8 Dec 2014

HAL is a multi-disciplinary open access archive for the deposit and dissemination of scientific research documents, whether they are published or not. The documents may come from teaching and research institutions in France or abroad, or from public or private research centers.
L'archive ouverte pluridisciplinaire HAL, est destinée au dépôt et à la diffusion de documents scientifiques de niveau recherche, publiés ou non, émanant des établissements d'enseignement et de recherche français ou étrangers, des laboratoires publics ou privés. 


\section{Biomarkers of CD4+ $\mathrm{T}$ cell activation as risk factors for tuberculosis-associated Immune Reconstitution Inflammatory Syndrome}

Lisa A. CHAKRABARTI ${ }^{1}$, Céline BOUCHERIE ${ }^{2,3}$, Florence BUGAULT ${ }^{4}$, Marie-Christine CUMONT $^{4}$, Caroline ROUSSILLON ${ }^{2,3}$, Guillaume BRETON ${ }^{5}$, Olivier PATEY ${ }^{6}$, Geneviève CHÊNE $^{2,3,7}$, Laura RICHERT ${ }^{2,3}$, Olivier LORTHOLARY ${ }^{8}$ and the ANRS 129 BKVIR-CYTOK STUDY GROUP

1 Unité de Pathogénie Virale, Institut Pasteur, Paris, France

2 Univ. Bordeaux, ISPED, Centre INSERM U897-Epidemiologie-Biostatistique, F-33000 Bordeaux, France

3 INSERM ISPED, Centre INSERM U897-Epidemiologie-Biostatistique, F-33000 Bordeaux, France

4 Unité d'Immunologie Cellulaire, Institut Pasteur, Paris, France

5 Service de Médecine Interne, Hôpital de La Pitié-Salpêtrière, Paris, France

6 Hôpital Villeneuve St-Georges, Villeneuve St-Georges, France

$7 \mathrm{CHU}$ de Bordeaux, Pole de santé publique, Service d'information médicale, F-33000 Bordeaux, France

8 Université Paris Descartes, Hôpital Necker Enfants malades, APHP, Paris, France.

Running head: CD4 activation biomarkers in TB-IRIS

Abstract word count: 247 words

Manuscript word count: 3,935 words

Correspondence: Lisa A. Chakrabarti, Institut Pasteur, Unité de Pathogénie Virale, 28 rue du Dr Roux, 75724 Paris Cedex 15, France.

E-mail: chakra@pasteur.fr Tel: ${ }^{+} 33145688945 \quad$ Fax: ${ }^{+} 33145688941$

Funding: The ANRS 129 BKVIR trial was sponsored by the National Agency for Research on AIDS and Viral Hepatitis (ANRS). The BKVIR-CYTOK sub-study was funded by a grant from Sidaction to L.A.C. Bristol-Meyer Squibb provided efavirenz and Gilead Sciences provided tenofovir DF- emtricitabine for the trial. L. R. was the recipient of a young investigator grant from Sidaction (http://www.sidaction.org). 


\section{ABSTRACT}

Objective: Patients co-infected with HIV and Mycobacterium tuberculosis frequently experience a paradoxical worsening of tuberculosis (TB) symptoms early after the initiation of combination antiretroviral therapy (cART). This immune reconstitution inflammatory syndrome (TB-IRIS) can lead to significant morbidity and needs to be distinguished from TB recurrence due to ineffective treatment. We investigated whether plasma biomarkers could predict the occurrence of TB-IRIS.

Design: ANRS 129 BKVIR is a single-arm multi-center trial that enrolled 69 cART naive HIV-1 infected patients treated for TB. The patients received once daily tenofovir/emtricitabine/efavirenz first-line regimen. TB-IRIS cases (IRIS+) were validated by an Event Review Committee.

Methods: A panel of 26 plasma biomarkers was monitored longitudinally for 24 weeks from CART initiation onward, using multiplexed assays and high-sensitivity ELISA. Statistical analyses of biomarkers were adjusted for test multiplicity.

Results: A third of patients $(n=23)$ experienced TB-IRIS. The inflammatory cytokines and chemokines IL-6, IL-8/CXCL8, IP-10/CXCL10, and TNF- $\alpha$ showed increased plasma levels at wk4 in IRIS+ patients ( $P<0.05$ for each biomarker). The soluble IL-2 receptor SCD25, which is released upon CD4+ T cell activation, was significantly increased at wk0 in IRIS+ patients $(P<0.05)$, and remained elevated throughout follow-up. IL-7, a key homeostatic cytokine for CD4+ T cells, showed a trend for higher values in the TB-IRIS group. Both SCD25 and IL-7 baseline levels were independently associated with a shorter time to TBIRIS occurrence ( $P=0.005$ and $P=0.02$, respectively).

Conclusions: These findings support a role for $C D 4+T$ cell activation prior to massive inflammation in the development of TB-IRIS.

Keywords: Immune Reconstitution Inflammatory Syndrome; HIV; tuberculosis; biomarker; IL-7; soluble IL-2 receptor. 


\section{INTRODUCTION}

Co-infection with Mycobacterium tuberculosis (Mtb) and HIV represents a major threat to public health worldwide [1]. Tuberculosis (TB) is frequent and severe in HIV-infected patients, who often present with atypical symptoms and extra-pulmonary Mtb dissemination $[2,3]$. TB treatment is more difficult to manage in HIV-infected patients due to pharmacological interactions with antiretroviral drugs and to a higher frequency of multi-drug resistant TB strains [4]. Moreover, the treatment of HIV and Mtb co-infected patients can be complicated by the occurrence of an Immune Reconstitution Inflammatory Syndrome (IRIS), which is manifested by a recurrence of TB symptoms after the initiation of combination antiretroviral therapy (CART) [5, 6]. Two major forms of TB-IRIS can be distinguished, including a "paradoxical" form occurring in patients who were previously treated for TB, and an "unmasking" form occurring in patients not known to be infected with Mtb and in whom TB symptoms are recognized only after CART initiation. TB-IRIS causes significant morbidity, especially in resource-limited settings, and is life-threatening when associated with meningeal or cerebral granulomatous reaction [7-9].

IRIS is thought to result from a rapid recovery of immune responses against opportunistic pathogens, resulting in a massive inflammatory reaction directed against pathogen-loaded tissues. The factors most commonly associated with IRIS occurrence are a high pathogen burden and an advanced state of immunosuppression, as indicated by a very low CD4+ T cell count at cART initiation [10, 11]. An immunological hallmark of IRIS is the rapid expansion of CD4+ T cells specific for the causal opportunistic pathogen, while CD4+ T cells specific for HIV remain stable [12, 13]. During TB-IRIS, CD4+ T cells specific for Purified Protein Derivative (PPD) antigens show massive proliferation, activation, and release of Th1type cytokines [14, 15]. Macrophages also appear involved in IRIS pathogenesis, as suggested by marked increases in inflammatory markers such as interleukin (IL)-6, tumor necrosis factor (TNF)- $\alpha$ and C-reactive protein (CRP) [16-18] and by accumulation of CD68+ macrophages at IRIS lesion sites [19, 20]. The anti-inflammatory cytokine IL-10 is also increased in the course of TB-IRIS, which may reflect the activation of immunoregulatory mechanisms counteracting the deleterious effects of inflammation [21]. Finally, innate immune cells other than macrophages may also play a role in IRIS pathogenesis, as evidenced by an increase in KIR-negative $\gamma \delta$ T cells [14], a higher degranulation capacity of natural killer cells [11], and a higher expression of TLR2 on myeloid dendritic cells [22] at cART initiation in patients who subsequently develop TB-IRIS.

Though helpful IRIS clinical criteria have been validated by the International Network for the Study of HIV-associated IRIS (INSHI) [7], the diagnosis of TB-IRIS is not straightforward [23, 
24]. It is necessary to distinguish TB-IRIS from a recurrence of TB due to drug resistance or non-observance of anti-mycobacterial treatment, and to rule out the onset of a new opportunistic infection. Defining parameters predictive of IRIS occurrence represents an important objective, as these may impact case management. Several plasma biomarkers measured before or at the time of CART initiation have shown significant changes in patients who subsequently developed TB-IRIS, though a consensus on the most informative markers remains to be established. The combination of an increase in IL-18 and IP-10/CXCL10 with a decrease of CCL2 was predictive of paradoxical TB-IRIS in a cohort of Cambodian patients [25]. In two studies, markers of inflammation, such as CRP, D-dimer, or IL-6 were increased at baseline in patients who developed IRIS [26, 27]. In a third study, increased levels of plasma IFN- $\gamma$ and CRP were predictive of unmasking TB-IRIS, but not of paradoxical TBIRIS [28]. Thus, while both Th1-derived cytokines and innate inflammatory markers appear dysregulated in IRIS pathogenesis [16], there is a need to further define predictive markers of IRIS and to characterize the chain of events leading to the cytokine storm characteristic of TB-IRIS.

\section{METHODS}

\section{Study population}

ANRS 129 BKVIR was a phase II single-arm multi-center trial that enrolled 69 antiretroviral naive HIV-1 infected patients treated for TB in France [29]. Briefly, eligible patients were HIV1 infected individuals aged $\geq 18$ years, with microbiologically or histologically confirmed TB, treated with anti-tuberculosis drugs for less than 12 weeks, and naive of CART. The CD4+ T cell counts were not a criterion for inclusion in the trial. Patients received a first-line cART regimen consisting in a once-daily combination of tenofovir DF (300 mg/day)/emtricitabine (200 mg/day) and efavirenz (800mg/day if treated by rifampin, otherwise $600 \mathrm{mg} /$ day). TBIRIS cases (IRIS+) were classified according to the criteria defined by French et al. [30] and by the INSHI [7]. All TB-IRIS cases were validated by an Event Review Committee, based on a detailed review of medical charts. Written informed consent was obtained for all trial participants. The ANRS 129 BKVIR trial and the BKVIR-CYTOK sub-study were approved by the ethics committee "Comité de Protection des Personnes CPP lle de France II".

\section{Biomarker measurements}

Biomarkers were monitored longitudinally at cART initiation, at week 0 (wk0), and at wk4, wk12 and wk24 on plasma samples stored at $-80^{\circ} \mathrm{C}$. A panel of 26 biomarkers, including homeostatic cytokines, inflammatory cytokines and chemokines, was tested by multiplex

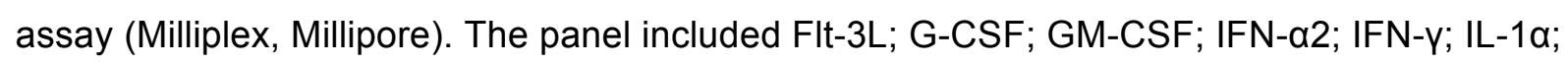


IL-1ra; IL-2; IL-4; IL-5; IL-6; IL-8/CXCL8; IL-9; IL-10; IL-12 (p40); IL-12 (p70); IL-15; IL-17; IP-

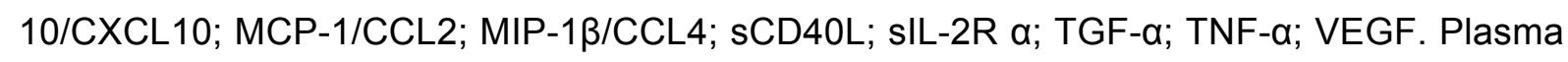
samples collected on EDTA $(100 \mu \mathrm{l})$ were tested in duplicate for the 26 biomarkers simultaneously, using a Luminex 100 reader (GMI, Inc.). Data was analyzed in the Starstation 2.3 software (Applied Cytometry Systems). Concentrations were derived from fluorescence intensities (FI) by 5-parameters logistic curves. The cytokine IL-7 was measured separately on duplicate samples by a high-sensitivity ELISA assay (Quantikine HS kit, R\&D systems). Multiplex and ELISA assays were done in parallel on plasma samples that were thawed just once to optimize the sensitivity of biomarker measurements.

\section{Statistical analysis}

Comparisons of clinical parameters between the IRIS+ and IRIS- groups were made by Mann-Whitney tests for quantitative variables and $\mathrm{Khi}^{2}$ tests for qualitative variables. Analyses of biomarkers were performed on fluorescence intensities (FI) and derived concentrations. Descriptive analyses were done for all biomarkers, but statistical comparisons were limited to 11 pre-defined biomarkers of interest (IFN-Y; IL-1a; IL-1ra; IL-12 (p40); IL-6; IL-7; IL-8; IP-10; sCD40L; sIL-2Ra; TNF- $\alpha$ ). Levels of these biomarkers were compared between the IRIS+ and IRIS- groups at four time points by Mann-Whitney tests, with an adjustment of P-values for test multiplicity (adaptive false discovery rate, FDR) [31]. $\mathrm{P}$-values based on $\mathrm{FI}$ were considered the primary analyses, given that statistical comparisons of concentrations could be limited by missing or censored values [32]. Cox proportional hazards models with a step-wise backward selection procedure were performed to determine whether a panel of three biomarkers chosen on a pathophysiologic basis (IL-7; IP-10; sIL-2Ra) allowed to predict the time to IRIS occurrence. A logistic regression, that modeled IRIS occurrence independently of time, was used as robustness analysis. The kinetics of IP-10 decrease was evaluated with a linear mixed effect model. All statistical analyses were performed with SAS software version 9.1.3 (SAS Institute Inc., Cary, NC, USA).

\section{RESULTS}

\section{Frequent and rapid occurrence of TB-IRIS}

The characteristics of the 69 patients co-infected with HIV-1 and Mtb are reported in Table 1. Most patients were male and half of them (54\%) were born in Sub-Saharan Africa. CD4+ T cell counts were generally low (median: $74 / \mathrm{mm}^{3}$ ) and a majority of patients had disseminated TB $(71 \%)$, indicative of advanced immunodeficiency. A third of patients $(33 \%, n=23)$ 
developed TB IRIS after CART initiation. Five IRIS events were considered serious, including two acute renal failures, two cerebral tuberculoma, including one with seizures and one with intracranial hypertension, and one segmental bronchial compression. Baseline plasma HIV-1 RNA was slightly higher in patients with than without IRIS (5.5 versus $5.1 \log _{10}$ copies $/ \mathrm{mL}$, $p=0.020$ ). The median period between start of anti-mycobacterial therapy and cART was shorter in patients with than without IRIS (46 vs 61 days, $p=0.026$ ). Following cART initiation, the median time to IRIS onset was 8 days (interquartile range (IQR): $5-14$ ), and $87 \%$ of IRIS cases occurred before wk4.

\section{Induction of inflammatory mediators during TB-IRIS}

Five biomarkers showed significant differences between the IRIS $+(n=23)$ and IRIS- $(n=46)$ groups of patients. Table 2 summarizes data for these markers at early time points (wk0 and wk4). Four biomarkers characteristic of inflammation showed an increased plasma concentration at wk4 in the IRIS+ group compared to the IRIS- group: IL-6, TNF- $\alpha$, IL8/CXCL8, and IP-10/CXCL10 (Fig. 1). At CART initiation (wk0), the levels of these inflammatory mediators did not differ between IRIS+ and IRIS- patients. IL-6, IL-8, and TNF$\alpha$ were rapidly induced in the IRIS+ group during the first weeks of cART (Fig. 1A). Subsequently, IL-6 returned to baseline levels at wk12, while IL-8 and TNF- $\alpha$ showed a trend for increased levels in the IRIS+ group throughout follow-up. Thus, IRIS was characterized by a massive inflammation that persisted to some extent for up to 6 months.

The chemokine IP-10 did not follow the same kinetics as the other inflammatory mediators, but rather decreased continuously from wk0 to wk12. In the IRIS- group, the IP-10 plasma concentration decreased in parallel with HIV-1 RNA after CART initiation, while the decrease appeared slower in the IRIS+ group (Fig.1B). Analysis by a linear mixed effect model showed that, in the IRIS- group, the IP-10 concentration decreased significantly between wk0 and wk4 (-384 pg/ml per week [95\% confidence interval $(\mathrm{Cl}):-612 ;-156], \mathrm{p}=0.0013)$, as well as between wk4 and wk12 (-158 pg/ml per week [95\% Cl: -222;-94], p<0.0001). The decrease in IP-10 appeared less marked in the IRIS+ group $(p=0.098)$ during the first 4 weeks, with a mean loss of $-52 \mathrm{pg} / \mathrm{ml}$ per week $(95 \% \mathrm{Cl}:-374 ;+270)$. Between wk4 and wk12, changes in IP-10 concentration were comparable between both groups $(p=0.30)$, with a mean loss of $216 \mathrm{pg} / \mathrm{ml}$ per week $(95 \% \mathrm{Cl}:-305 ;-127)$ in the IRIS+ group. Thus, while baseline IP-10 levels did not differ between groups, the decrease after CART initiation tended to be slower in the IRIS+ group. In contrast, the kinetics of HIV-1 RNA decrease was superimposable in patients with and without IRIS (Fig. 1C), suggesting a comparable efficacy of cART regimen in both groups. 


\section{Increased markers of CD4+ $T$ cell activation in TB-IRIS patients}

The homeostatic cytokine IL-7 was studied because of its key role in CD4+ T cell survival and proliferation [33]. As preliminary experiments showed that the sensitivity of IL-7 detection was low in multiplexed assays, we measured IL-7 separately by a high sensitivity ELISA assay. IL-7 showed a non-significant trend for persistently higher levels in the IRIS+ group at wk0 and throughout follow-up (Fig. 2A). CD4+ T cell counts did not differ between the IRIS+ and IRIS- groups at wk0 as well as during the immune reconstitution phase (Fig. 2B). Thus, the trend for higher plasma IL-7 levels in the IRIS+ group could not be explained by a smaller CD4+ T cell pool that would have resulted in decreased IL-7 consumption.

The alpha chain of the IL-2 receptor, CD25/IL-2R $\alpha$, is predominantly expressed by CD4+ T cells and is released by proteolytic cleavage from the surface of activated T cells [34, 35]. The baseline plasma level of soluble CD25 (SCD25) was significantly higher in the IRIS+ group as compared to the IRIS- group, and showed further increase with a peak at wk4 and a progressive decline thereafter (Fig. 4C). The concentrations of sCD25 remained significantly higher in the IRIS+ group throughout follow-up, pointing to $\mathrm{T}$ cell activation as a major contributor to IRIS pathogenesis.

\section{IL-7 and SCD25 levels are independently associated with TB-IRIS occurrence}

We next studied whether the baseline concentration of the IL-7, SCD25, and IP-10 markers were associated with the subsequent occurrence of TB-IRIS. Baseline values of two bioclinical parameters, hemoglobin and body mass index (BMI), were also included in the model (supplementary Table 1), as these parameters had been found to be associated with TB-IRIS occurrence in multivariable analyses of the BKVIR core trial [29]. In the final Cox proportional hazards model (Table $3 A)$, only IL-7 $(p=0.022)$ and $\operatorname{sCD} 25(p=0.005)$ were independently associated with TB-IRIS occurrence. Robustness analysis using a logistic regression model yielded consistent results (Table $3 \mathrm{~A})$.

\section{Baseline IL-7 determines inflammatory cytokine induction}

We then determined whether the baseline levels of IL-7 and SCD25, as well as hemoglobin and BMI, were associated with the levels of the three inflammatory cytokines/chemokines that were significantly increased at wk4 in the IRIS+ group (IL-6, IL-8, TNF- $\alpha$ ). In the linear regression models, IL-7 baseline values at wk0 were positively associated with IL-6, IL-8, and TNF- $\alpha$ levels at wk4 (Table 3B). In contrast, no significant associations with sCD25 baseline levels were detected. Of the two clinical parameters, only baseline hemoglobin showed an independent association with inflammatory cytokines levels at wk4. Taken 
together, these findings suggested a role for IL-7 availability in the induction of inflammation during TB-IRIS.

\section{DISCUSSION}

In this study, we analyzed plasma biomarkers in naïve HIV-1 infected patients with confirmed Mtb infection and who initiated cART. The high rate of TB-IRIS occurrence in this wellcharacterized study population allowed the identification of biomarkers associated with IRIS. The plasma levels of the cytokines and chemokines IL-6, IL-8, TNF- $\alpha$, and IP-10 were significantly increased during TB-IRIS, consistent with an underlying role of the inflammatory response in the pathogenesis of IRIS. However, the biomarkers that predicted IRIS occurrence at the time of CART initiation were those associated with CD4+ $T$ cell activation rather than the inflammatory mediators. Indeed, both IL-7 and SCD25 were independently associated with TB-IRIS occurrence. IL-7 is a $\gamma$ c family cytokine that is considered as the master regulator of CD4+ $\mathrm{T}$ cell homeostasis, by promoting $\mathrm{T}$ cell survival, activation, and proliferation [36]. As such, IL-7 may contribute to the massive CD4+ T cell proliferation that characterizes the acute phase of TB-IRIS $[12,13]$. The soluble form of the IL-2 receptor, SCD25, is primarily released by activated CD4+ $T$ cells though proteolytic processing [34, 35], and is known to be increased in infectious, autoimmune, and malignant diseases characterized by chronic $T$ cell activation $[34,37,38]$. Thus, our findings support a key role for CD4+ T cell activation in the pathogenesis of IRIS.

The sequential increase of SCD25 and IL-7 followed by inflammatory markers in patients with TB-IRIS suggest a two-stage pathogenic process where CD4+ $T$ cell activation precedes inflammation. This notion is supported by the positive association between IL-7 baseline values at $w k 0$ and inflammatory cytokine values at wk4, a time point by which the majority of IRIS-TB events had occurred. Advanced HIV infection is known to be associated with a chronic activation of dysfunctional $T$ cells that show signs of functional exhaustion and increased apoptosis [39]. Abundant mycobacterial antigens present in TB-infected patients may further drive the activation of $C D 4+T$ cells that remain dysfunctional and fail to proliferate during the phase of active HIV replication. Our findings suggest that patients with higher levels of CD4+ T cell activation at CART initiation are more prone to develop TB-IRIS, possibly because of a rapid functional recovery of this pre-activated CD4+ T cell population. The notion of a prominent but abnormal CD4+ T cell activation prior to IRIS is supported by a study showing increased levels of the inhibitory costimulatory molecules PD-1, LAG-3, and CTLA-4 in CD4+ T cells of patients before IRIS occurrence [40]. 
Increased IL-7 levels may also prime CD4+ T cells for rapid proliferation once viral replication is controlled. We and others have shown that IL-7 responses are impaired in CD4+ T cells of patients with detectable HIV load, due to IL-7 receptor down-regulation [41] and perturbed IL7 downstream signaling [42, 43]. Importantly, functional IL-7 responses are recovered under CART, allowing for the reconstitution of the CD4+ T cell pool. Higher IL-7 levels in patients with IRIS likely contribute to the massive proliferation of Mtb-specific CD4+ T cells that occurs once CART is initiated [14, 15]. Consistent with our results, two studies found evidence for persistently elevated IL-7 concentrations in patients with IRIS [40, 44], suggesting a prolonged effect of this cytokine. The determinants of increased IL-7 levels in patients with IRIS remain to be elucidated. An inverse correlation between CD4+ T cell counts and IL-7 levels has been documented in HIV-infected patients, suggesting that increases in IL-7 result from a decreased consumption of this cytokine by CD4+ T cells [45]. Increased IL-7 levels would in turn promote CD4+ $T$ cell survival and proliferation, contributing to the reconstitution of CD4+ $T$ cell population. While this homeostatic mechanism is likely at work in IRIS patients, it is not sufficient to account for the higher IL-7 levels, given that CD4+ T cell counts were not significantly lower than in patients without IRIS. IL-7 had long been thought to be constitutively produced by stromal cells within lymphoid organs, but recent studies have revealed that hepatocytes are capable of inducible IL-7 production when stimulated by type I interferons or inflammatory mediators [46]. In addition, specialized lymph node and thymic stromal cells, as well as lymphatic endothelial cells, can increase their IL-7 production in response to lymphopenia [47, 48]. Thus, the possibility that patients with higher inducible IL-7 production may be more susceptible to TBIRIS warrants further investigation.

The nature of the cytokines and chemokines induced during TB-IRIS, including TNF- $\alpha$, IL-6, and IL-8, is indicative of inflammation mediated primarily by macrophages, though the contribution of other innate cells and of stromal cells is also possible. These findings are in agreement with studies showing increases in inflammatory mediators during IRIS induced by Mtb [25, 28] and other opportunistic pathogens such as Pneumocystis jiroveci and Cryptococcus neoformans $[49,50]$. Considering that memory CD4+ T cells are potent activators of macrophages [51], it is likely that the rapid recovery of CD4+ T cell helper functions under cART contributes to the activation of macrophages loaded with Mtb and underlies the massive inflammation characteristic of IRIS. This two-step scenario would explain in particular why CD4+ T cell activation precedes that of macrophages in TB-IRIS. This notion is also compatible with the model of IRIS pathogenesis recently proposed by Barber et al., based on experiments in T cell deficient mice infected with M. avium [17, 52]. In this model, IRIS results from a dysregulated response of macrophages that were primed in 
the absence of CD4+ T cell help, with the sudden transfer of CD4+ T cells leading to macrophage hyper-responsiveness and tissue-destructive inflammation. While this model strongly supports a role for macrophage dysregulation in IRIS pathogenesis, it does not account for the increased activation of CD4+ T cells prior to IRIS. One possibility is that Mtbspecific CD4+ $T$ cells also undergo prolonged priming in suboptimal conditions during the stage of active HIV replication, resulting in dysregulated Th1 responses after cART initiation.

Of note, a study of TB-IRIS found that a combination of increased IL-18 and IP-10 levels, with decreased CCL2 levels, was predictive of TB-IRIS occurrence [25]. These findings suggest that some but not all inflammatory mediators may be induced prior to IRIS, consistent with macrophage dysregulation. We did not detect increased IP-10 levels at baseline in the present study, possibly because patients in the BKVIR trial had slightly higher CD4+ $T$ cell counts, or because of differences in experimental setup, as we measured IP-10 directly in plasma rather than after overnight culture [25]. Interestingly, IP-10 showed a different kinetics than other inflammatory mediators, with a high concentration at baseline and a continuous decrease that paralleled that of the viral load. The induction of IP-10 in situations of high viral load, which has also been reported during primary HIV infection [53], may be explained by the facts that IP-10 is a chemokine primarily induced by type 1 and type 2 interferons [54], and that HIV is both a direct inductor of type 1 interferons though the innate response and of type 2 interferon through the adaptive response. The observation that IP-10 levels decreased more slowly in patients with IRIS suggests that the persistence of an interferon response may contribute to the pathogenesis of IRIS. Persistently high levels of IP10 in patients with IRIS is a consistent finding, as it has been observed in TB-IRIS [16, 25] but also in IRIS triggered by other pathogens. For instance, HIV/HBV coinfected patients who develop hepatic flares after cART initiation show a persisting increase of IP-10, while patients without signs of hepatic inflammation maintain moderate levels of the chemokine [55]. As HIV loads are rapidly decreasing during IRIS, the persistence of IP-10 may not be virally driven, but may rather reflect a strong IFN- $\gamma$-dependent adaptive response. In the present study, while we did not detect significant differences between the IRIS+ and IRIS- groups in IFN- $\alpha 2$ and IFN- $\gamma$ levels, we noted a trend for higher IFN- $\gamma$ values at wk4 in IRIS patients. Approaches based on the analysis of IFN- $\gamma$ induction after PPD antigenic stimulation in vitro have documented a consistent increase in IFN- $\gamma$ secretion during TB-IRIS $[12,13,15,56]$. Thus, the persistence of high IP-10 levels may be a sensitive indicator of an ongoing Th1 response. Considering that IP-10 plays an important role in the differentiation of Th1 cells within lymphoid tissues [57], and in the recruitment of effector T cells to inflamed tissues [54], it is likely that this chemokine contributes to a positive feedback loop driving Th1 cell 
activation during TB-IRIS. Our study has limitations due to the relatively limited size of the cohort studied and the fact that patient peripheral blood cells were not available for analyses. Therefore, it will be important in future studies to include an analysis of CD4+ T cell phenotype and cytokine secretion capacity, to confirm a predominant role of activated Th1 cells in triggering and sustaining TB-IRIS.

Patients who developed TB-IRIS in the ANRS 129 BKVIR trial had slightly higher viral loads than patients who did not show signs of TB-IRIS. One reason may be that HIV directly contributes to the abnormal activation that primes immune cells for TB-IRIS. In addition, a higher viral burden may be associated with a more advanced stage of TB, and hence with a higher load of $M t b$ antigens available to prime a dysregulated immune response. Mycobacteria can in turn promote HIV replication through the release of TNF- $\alpha$ [58], resulting in synergistic interactions between the two pathogens. Patients in the IRIS+ group also had a shorter delay between the initiation of anti-TB therapy and cART than patients in the IRISgroup, a finding in agreement with published studies [23, 59-61], and which may reflect the lower load of $M t b$ antigens in patients who have been treated for a longer time with antituberculous drugs. Importantly, large clinical trials have demonstrated that even though shortening the delay to cART to 2-4 weeks increases the risk of TB-IRIS in HIV/Mtb coinfected patients, this approach is beneficial in patients with very low CD4+ T cell counts $\left(<50\right.$ cells $\left./ \mathrm{mm}^{3}\right)$, as it limits AIDS-associated mortality [59-61]. Thus, as early cART emerges as the strategy of choice in HIVIMtb coinfected patients with advanced immunosuppression, it becomes all the more important to validate predictive markers that can help focus limited medical resources on patients at high risk of TB-IRIS.

In conclusion, this study shows that patients at high-risk of TB-IRIS have signs of preexisting CD4+ T cell activation, as indicated by increased circulating levels of SCD25 and increased availability of IL-7. After CART initiation, TB-IRIS patients showed rapid increases of the inflammatory mediators IL-6, IL-8, TNF- $\alpha$, and IP-10 in plasma. These findings support a role for CD4+ $T$ cell activation prior to massive inflammation in the development of TB-IRIS. Further validation of these results on an independent cohort of patients should help determine the potential of SCD25 and IL-7 as predictive biomarkers of patients at high risk of TB-IRIS. 


\section{ACKNOWLEDGEMENTS}

We are grateful to the patients who participated in the ANRS 129 BKVIR trial. We thank all the investigators of the ANRS 129 BKVIR trial (supplementary file 1) and the members of the Event Review Committee who validated IRIS cases (supplementary file 1). We thank BristolMeyer Squibb and Gilead Sciences for providing drugs used in the ANRS 129 BKVIR trial. We acknowledge the Center for Human Immunology at Institut Pasteur for support in conducting this study, and we thank Milena Hasan and Helen Law for advice on multiplex experiments.

Authors contributions: O.L. was the principal investigator of the ANRS 129 BKVIR clinical trial, which was conducted by C.R., G.B., O.P., and G.C. L.C., C.R., and O.L. designed the biomarker substudy. F.B. and M.C.C. performed the biomarkers measurements. L.C., C.B., L.R., and G.C. analyzed the data. L.C., C.B., and L.R. wrote the manuscript. All authors read and approved the final manuscript. 


\section{BIBLIOGRAPHY}

1. Zumla A, Raviglione M, Hafner R, von Reyn CF. Tuberculosis. N Engl J Med 2013,368:745-755.

2. Ackah AN, Coulibaly D, Digbeu H, Diallo K, Vetter KM, Coulibaly IM, et al. Response to treatment, mortality, and CD4 lymphocyte counts in HIV-infected persons with tuberculosis in Abidjan, Cote d'Ivoire. Lancet 1995,345:607-610.

3. Aaron L, Saadoun D, Calatroni I, Launay O, Memain N, Vincent V, et al. Tuberculosis in HIV-infected patients: a comprehensive review. Clin Microbiol Infect 2004,10:388-398.

4. Gandhi NR, Moll A, Sturm AW, Pawinski R, Govender T, Lalloo U, et al. Extensively drug-resistant tuberculosis as a cause of death in patients co-infected with tuberculosis and HIV in a rural area of South Africa. Lancet 2006,368:1575-1580.

5. Muller M, Wandel S, Colebunders R, Attia S, Furrer H, Egger M, et al. Immune reconstitution inflammatory syndrome in patients starting antiretroviral therapy for HIV infection: a systematic review and meta-analysis. Lancet Infect Dis 2010,10:251-261.

6. Breton G, Duval X, Estellat C, Poaletti X, Bonnet D, Mvondo Mvondo D, et al. Determinants of immune reconstitution inflammatory syndrome in HIV type 1-infected patients with tuberculosis after initiation of antiretroviral therapy. Clin Infect Dis 2004,39:1709-1712.

7. Meintjes G, Lawn SD, Scano F, Maartens G, French MA, Worodria W, et al. Tuberculosis-associated immune reconstitution inflammatory syndrome: case definitions for use in resource-limited settings. Lancet Infect Dis 2008,8:516-523.

8. Marais S, Meintjes G, Pepper DJ, Dodd LE, Schutz C, Ismail Z, et al. Frequency, severity, and prediction of tuberculous meningitis immune reconstitution inflammatory syndrome. Clin Infect Dis 2013,56:450-460.

9. Agarwal U, Kumar A, Behera D, French MA, Price P. Tuberculosis associated immune reconstitution inflammatory syndrome in patients infected with HIV: meningitis a potentially life threatening manifestation. AIDS Res Ther 2012,9:17.

10. French MA. The immunopathogenesis of mycobacterial immune restoration disease. Lancet Infect Dis 2006,6:461-462.

11. Pean P, Nerrienet E, Madec Y, Borand L, Laureillard D, Fernandez M, et al. Natural killer cell degranulation capacity predicts early onset of the immune reconstitution inflammatory syndrome (IRIS) in HIV-infected patients with tuberculosis. Blood 2012,119:3315-3320. 
12. Bourgarit A, Carcelain G, Martinez V, Lascoux C, Delcey V, Gicquel B, et al. Explosion of tuberculin-specific Th1-responses induces immune restoration syndrome in tuberculosis and HIV co-infected patients. Aids 2006,20:F1-7.

13. Mahnke YD, Greenwald JH, DerSimonian R, Roby G, Antonelli LR, Sher A, et al. Selective expansion of polyfunctional pathogen-specific CD4(+) T cells in HIV-1-infected patients with immune reconstitution inflammatory syndrome. Blood 2012,119:31053112.

14. Bourgarit A, Carcelain G, Samri A, Parizot C, Lafaurie M, Abgrall S, et al. Tuberculosisassociated immune restoration syndrome in HIV-1-infected patients involves tuberculinspecific CD4 Th1 cells and KIR-negative gammadelta $\mathrm{T}$ cells. $\mathrm{J}$ Immunol 2009,183:3915-3923.

15. Elliott JH, Vohith K, Saramony S, Savuth C, Dara C, Sarim C, et al. Immunopathogenesis and diagnosis of tuberculosis and tuberculosis-associated immune reconstitution inflammatory syndrome during early antiretroviral therapy. $J$ Infect Dis 2009,200:1736-1745.

16. Sereti I, Rodger AJ, French MA. Biomarkers in immune reconstitution inflammatory syndrome: signals from pathogenesis. Curr Opin HIV AIDS 2010,5:504-510.

17. Barber DL, Andrade BB, Sereti I, Sher A. Immune reconstitution inflammatory syndrome: the trouble with immunity when you had none. Nat Rev Microbiol 2012,10:150-156.

18. Tadokera R, Meintjes G, Skolimowska KH, Wilkinson KA, Matthews K, Seldon R, et al. Hypercytokinaemia accompanies HIV-tuberculosis immune reconstitution inflammatory syndrome. Eur Respir J 2011,37:1248-1259.

19. Lortholary O, Fontanet A, Memain N, Martin A, Sitbon K, Dromer F. Incidence and risk factors of immune reconstitution inflammatory syndrome complicating HIV-associated cryptococcosis in France. Aids 2005,19:1043-1049.

20. Lawn SD, Wainwright $\mathrm{H}$, Orrell $\mathrm{C}$. Fatal unmasking tuberculosis immune reconstitution disease with bronchiolitis obliterans organizing pneumonia: the role of macrophages. AIDS 2009,23:143-145.

21. Tadokera R, Wilkinson KA, Meintjes GA, Skolimowska KH, Matthews K, Seldon R, et al. Role of the Interleukin 10 Family of Cytokines in Patients With Immune Reconstitution Inflammatory Syndrome Associated With HIV Infection and Tuberculosis. J Infect Dis 2013. 
22. Tan DB, Lim A, Yong YK, Ponnampalavanar S, Omar S, Kamarulzaman A, et al. TLR2induced cytokine responses may characterize HIV-infected patients experiencing mycobacterial immune restoration disease. AIDS 2011,25:1455-1460.

23. Breton G. Immune reconstitution inflammatory syndrome. In: Tuberculosis: $A$ comprehensive clinical reference. Edited by Schaaf HS, Zumla A. Philadelphia: Saunders, Elsevier; 2009. pp. 689-700.

24. Meintjes G, Scriven J, Marais S. Management of the immune reconstitution inflammatory syndrome. Curr HIVIAIDS Rep 2012,9:238-250.

25. Oliver BG, Elliott JH, Price P, Phillips M, Saphonn V, Vun MC, et al. Mediators of innate and adaptive immune responses differentially affect immune restoration disease associated with Mycobacterium tuberculosis in HIV patients beginning antiretroviral therapy. J Infect Dis 2010,202:1728-1737.

26. Porter BO, Ouedraogo GL, Hodge JN, Smith MA, Pau A, Roby G, et al. d-Dimer and CRP levels are elevated prior to antiretroviral treatment in patients who develop IRIS. Clin Immunol 2010,136:42-50.

27. Narendran G, Andrade BB, Porter BO, Chandrasekhar C, Venkatesan P, Menon PA, et al. Paradoxical tuberculosis immune reconstitution inflammatory syndrome (TB-IRIS) in HIV patients with culture confirmed pulmonary tuberculosis in India and the potential role of IL-6 in prediction. PLoS One 2013,8:e63541.

28. Haddow LJ, Dibben O, Moosa MY, Borrow P, Easterbrook PJ. Circulating inflammatory biomarkers can predict and characterize tuberculosis-associated immune reconstitution inflammatory syndrome. AIDS 2011,25:1163-1174.

29. Lortholary O, Roussillon C, Chaix ML, Boucherie C, Breton G, Padouin C, et al. Tenofovir DF/emtricitabine and efavirenz in HIV-1 infected patients treated for tuberculosis: ANRS 129 BKVIR trial. submitted.

30. French MA, Price P, Stone SF. Immune restoration disease after antiretroviral therapy. AIDS 2004,18:1615-1627 \%U http://www.ncbi.nlm.nih.gov/pubmed/15280772.

31. Benjamini $\mathrm{Y}$, Hochberg Y. On the Adaptive Control of the False Discovery Rate in Multiple Testing With Independent Statistics. Journal of Educational and Behavioural Statitics 2000,25:60-83.

32. Richert L, Hue S, Hocini H, Raimbault M, Lacabaratz C, Surenaud M, et al. Cytokine and gene transcription profiles of immune responses elicited by HIV lipopeptide vaccine in HIV-negative volunteers. AIDS 2013,27:1421-1431. 
33. Lundstrom W, Fewkes NM, Mackall CL. IL-7 in human health and disease. Semin Immunol 2012,24:218-224.

34. Rubin LA, Nelson DL. The soluble interleukin-2 receptor: biology, function, and clinical application. Ann Intern Med 1990,113:619-627.

35. Brusko TM, Wasserfall CH, Hulme MA, Cabrera R, Schatz D, Atkinson MA. Influence of membrane CD25 stability on T Iymphocyte activity: implications for immunoregulation. PLoS One 2009,4:e7980.

36. Mackall CL, Fry TJ, Gress RE. Harnessing the biology of IL-7 for therapeutic application. Nat Rev Immunol 2011,11:330-342.

37. Prince HE, Kleinman S, Williams AE. Soluble IL-2 receptor levels in serum from blood donors seropositive for HIV. J Immunol 1988,140:1139-1141.

38. Maier LM, Anderson DE, Severson CA, Baecher-Allan C, Healy B, Liu DV, et al. Soluble IL-2RA levels in multiple sclerosis subjects and the effect of soluble IL-2RA on immune responses. J Immunol 2009,182:1541-1547.

39. Deeks SG. HIV infection, inflammation, immunosenescence, and aging. Annu Rev Med 2011,62:141-155.

40. Antonelli LR, Mahnke Y, Hodge JN, Porter BO, Barber DL, DerSimonian R, et al. Elevated frequencies of highly activated CD4+ $\mathrm{T}$ cells in HIV+ patients developing immune reconstitution inflammatory syndrome. Blood 2010,116:3818-3827.

41. Chahroudi A, Silvestri G. Interleukin-7 in HIV pathogenesis and therapy. Eur Cytokine Netw 2010,21:202-207.

42. Juffroy O, Bugault F, Lambotte O, Landires I, Viard JP, Niel L, et al. Dual mechanism of impairment of interleukin-7 (IL-7) responses in human immunodeficiency virus infection: decreased IL-7 binding and abnormal activation of the JAK/STAT5 pathway. $J$ Virol 2010,84:96-108.

43. Landires I, Bugault F, Lambotte $O$, de Truchis P, Slama L, Danckaert A, et al. HIV infection perturbs interleukin-7 signaling at the step of STAT5 nuclear relocalization. AIDS 2011,25:1843-1853.

44. Seddiki N, Sasson SC, Santner-Nanan B, Munier M, van Bockel D, Ip S, et al. Proliferation of weakly suppressive regulatory CD4+ $\mathrm{T}$ cells is associated with overactive CD4+ T-cell responses in HIV-positive patients with mycobacterial immune restoration disease. Eur J Immunol 2009,39:391-403. 
45. Napolitano LA, Grant RM, Deeks SG, Schmidt D, De Rosa SC, Herzenberg LA, et al. Increased production of IL-7 accompanies HIV-1-mediated T-cell depletion: implications for T-cell homeostasis. Nature medicine 2001,7:73-79.

46. Sawa Y, Arima Y, Ogura H, Kitabayashi C, Jiang JJ, Fukushima T, et al. Hepatic interleukin-7 expression regulates T cell responses. Immunity 2009,30:447-457.

47. Alves NL, Huntington ND, Mention JJ, Richard-Le Goff O, Di Santo JP. Cutting Edge: a thymocyte-thymic epithelial cell cross-talk dynamically regulates intrathymic IL-7 expression in vivo. J Immunol 2010,184:5949-5953.

48. Miller CN, Hartigan-O'Connor DJ, Lee MS, Laidlaw G, Cornelissen IP, Matloubian M, et al. IL-7 production in murine lymphatic endothelial cells and induction in the setting of peripheral lymphopenia. Int Immunol 2013,25:471-483.

49. Grant PM, Komarow L, Lederman MM, Pahwa S, Zolopa AR, Andersen J, et al. Elevated interleukin 8 and T-helper 1 and T-helper 17 cytokine levels prior to antiretroviral therapy in participants who developed immune reconstitution inflammatory syndrome during ACTG A5164. J Infect Dis 2012,206:1715-1723.

50. Boulware DR, Meya DB, Bergemann TL, Wiesner DL, Rhein J, Musubire A, et al. Clinical features and serum biomarkers in HIV immune reconstitution inflammatory syndrome after cryptococcal meningitis: a prospective cohort study. PLoS Med 2010,7:e1000384.

51. Swain SL, McKinstry KK, Strutt TM. Expanding roles for CD4(+) T cells in immunity to viruses. Nat Rev Immunol 2012,12:136-148.

52. Barber DL, Mayer-Barber KD, Antonelli LR, Wilson MS, White S, Caspar P, et al. Th1driven immune reconstitution disease in Mycobacterium avium-infected mice. Blood 2010,116:3485-3493.

53. Liovat AS, Rey-Cuille MA, Lecuroux C, Jacquelin B, Girault I, Petitjean G, et al. Acute plasma biomarkers of $\mathrm{T}$ cell activation set-point levels and of disease progression in HIV-1 infection. PLoS One 2012,7:e46143.

54. Groom JR, Luster AD. CXCR3 ligands: redundant, collaborative and antagonistic functions. Immunol Cell Biol 2011,89:207-215.

55. Crane M, Oliver B, Matthews G, Avihingsanon A, Ubolyam S, Markovska V, et al. Immunopathogenesis of hepatic flare in HIV/hepatitis B virus (HBV)-coinfected individuals after the initiation of HBV-active antiretroviral therapy. $J$ Infect Dis 2009,199:974-981. 
56. Tan DB, Yong YK, Tan HY, Kamarulzaman A, Tan LH, Lim A, et al. Immunological profiles of immune restoration disease presenting as mycobacterial lymphadenitis and cryptococcal meningitis. HIV Med 2008,9:307-316.

57. Groom JR, Richmond J, Murooka TT, Sorensen EW, Sung JH, Bankert K, et al. CXCR3 chemokine receptor-ligand interactions in the lymph node optimize CD4+ T helper 1 cell differentiation. Immunity 2012,37:1091-1103.

58. Kitaura H, Ohara N, Kobayashi K, Yamada T. TNF-alpha-mediated multiplication of human immunodeficiency virus in chronically infected monocytoid cells by mycobacterial infection. APMIS 2001,109:533-540.

59. Blanc FX, Sok T, Laureillard D, Borand L, Rekacewicz C, Nerrienet E, et al. Earlier versus later start of antiretroviral therapy in HIV-infected adults with tuberculosis. $N$ Engl J Med 2011,365:1471-1481.

60. Abdool Karim SS, Naidoo K, Grobler A, Padayatchi N, Baxter C, Gray AL, et al. Integration of antiretroviral therapy with tuberculosis treatment. $N$ Engl $J$ Med 2011,365:1492-1501.

61. Havlir DV, Kendall MA, Ive P, Kumwenda J, Swindells S, Qasba SS, et al. Timing of antiretroviral therapy for HIV-1 infection and tuberculosis. N Engl J Med 2011,365:14821491. 


\section{LEGEND TO THE FIGURES}

\section{Figure 1: Induction of inflammatory mediators during IRIS}

( $A$ and $B$ ): The median and interquartile range (IQR) of biomarker concentrations are reported in $\mathrm{pg} / \mathrm{ml}$ for patients in the IRIS+ group (thick black line) and the IRIS- group (thin grey line) at the following time points: wk0, wk4, wk12, and wk24. A significant $P$ value $(P<0.05)$ after adjustment for test multiplicity is indicated by an asterisk.

(C) The viral load in the IRIS+ and IRIS- groups, measured as the log10 of the HIV-1 RNA copies/ml plasma, was followed for 48 weeks after cART initiation at week 0 . Median and IQR are reported on the graph.

\section{Figure 2: Induction of CD4+ T cell activation markers before and during TB-IRIS}

( $A$ and $C$ ): The median and interquartile range (IQR) of biomarker concentrations are reported in $\mathrm{pg} / \mathrm{ml}$ for patients in the IRIS+ group (thick black line) and the IRIS- group (thin grey line) at the following time points: wk0, wk4, wk12, and wk24. A significant $P$ value $(P<0.05)$ after adjustment for test multiplicity is indicated by an asterisk. A $P$ value $<0.01$ after adjustment for test multiplicity is indicated by a double asterisk.

(B) Changes in the number of CD4+ T cell lymphocytes per $\mathrm{mm}^{3}$ blood were followed for 48 weeks after CART initiation at week 0 . Median and IQR are reported on the graph. 


\begin{tabular}{|c|c|c|c|c|c|c|c|c|c|}
\hline \multirow{2}{*}{$\begin{array}{l}\text { Characteristics of patients } \\
\text { Male }\end{array}$} & \multirow[b]{2}{*}{$\mathrm{n}$} & \multirow[b]{2}{*}{$(\%)$} & \multicolumn{2}{|c|}{$\begin{array}{l}\text { Total } \\
(\mathrm{N}=69)\end{array}$} & \multicolumn{2}{|c|}{$\begin{array}{l}\text { IRIS+ } \\
(\mathrm{N}=23)\end{array}$} & \multicolumn{2}{|c|}{$\begin{array}{l}\text { IRIS- } \\
(\mathrm{N}=46)\end{array}$} & \multirow{2}{*}{$\begin{array}{c}\begin{array}{c}\mathbf{P} \\
\text { value }\end{array} \\
0.85\end{array}$} \\
\hline & & & 49 & $(71 \%)$ & 16 & $(70 \%)$ & 33 & $(72 \%)$ & \\
\hline Age (years) & median & $(I Q R)$ & 43 & $(34-52)$ & 48 & $(34-55)$ & 39 & $(34-48)$ & 0.47 \\
\hline Sub-Saharan African origin & $\mathrm{n}$ & $(\%)$ & 37 & $(54 \%)$ & 10 & $(43 \%)$ & 27 & $(59 \%)$ & 0.23 \\
\hline Body Mass Index (kg/m2) & median & $(I Q R)$ & 21 & $(19-24)$ & 21 & $(17-24)$ & 22 & $(19-24)$ & 0.09 \\
\hline Disseminated tuberculosis & $\mathrm{n}$ & $(\%)$ & 49 & $(71 \%)$ & 19 & $(83 \%)$ & 30 & $(65 \%)$ & 0.13 \\
\hline CD4+ T cells at Wk0 & median & $(I Q R)$ & 74 & $(23-159)$ & 69 & $(23-135)$ & 85 & $(20-201)$ & 0.52 \\
\hline $\begin{array}{l}\text { HIV Viral load at Wk0 } \\
\text { (log10 HIV-1 RNA copies/ml) }\end{array}$ & median & $(I Q R)$ & 5.4 & $(4.9-5.9)$ & 5.5 & $(5.2-6.1)$ & 5.1 & $(4.6-5.7)$ & 0.02 \\
\hline $\begin{array}{l}\text { Delay between anti-TB } \\
\text { therapy and ART (days) }\end{array}$ & median & (IQR) & 56 & $(37-73)$ & 46 & $(34-56)$ & 61 & $(43-74)$ & 0.03 \\
\hline
\end{tabular}

Table 1: Clinical and virological characteristics of patients with and without TB-IRIS - ANRS 129 BKVIR-CYTOK study

Demographic, clinical, and virological characteristics are reported for all patients included in the study (Total), and separatedly for patients withand without TB-IRIS (IRIS+ and IRIS- groups, respectively).

*: Raw $\mathrm{P}$ values are reported. $\mathrm{P}$ values corresponding to significant differences $(<0.05)$ between the last two groups are indicated in bold. 


\begin{tabular}{|c|c|c|c|c|c|c|c|}
\hline \multirow{2}{*}{$\begin{array}{l}\text { Time } \\
\text { point }\end{array}$} & \multirow{2}{*}{ Biomarker } & \multicolumn{2}{|c|}{ IRIS+ } & \multicolumn{2}{|c|}{ IRIS- } & \multirow{2}{*}{$\begin{array}{c}\text { Raw } \\
\text { P-value }\end{array}$} & \multirow{2}{*}{$\begin{array}{c}\text { Adaptive } \\
\text { FDR } \\
\text { P-value }\end{array}$} \\
\hline & & $\begin{array}{c}\text { median } \\
(\mathrm{pg} / \mathrm{ml})\end{array}$ & IQR & $\begin{array}{r}\text { Median } \\
(\mathrm{pg} / \mathrm{ml})\end{array}$ & IQR & & \\
\hline Wk 0 & IL-6 & 4 & [3-17] & 3 & [3-7] & 0.22 & 0.23 \\
\hline Wk 0 & IL-8 & 18 & [3-31] & 10 & [3-21] & 0.25 & 0.26 \\
\hline Wk 0 & TNF- $\alpha$ & 31 & [22-50] & 28 & [20-41] & 0.29 & 0.26 \\
\hline Wk 0 & IP-10 & 3913 & [2982-5748] & 3830 & [2411-5645] & 0.43 & 0.32 \\
\hline Wk 0 & IL-7 & 6 & {$[5-11]$} & 4 & {$[2-7]$} & 0.05 & 0.10 \\
\hline Wk 0 & sCD25 & 127 & [75-233] & 69 & [38-126] & 0.02 & 0.047 \\
\hline Wk 0 & $\mathrm{IFN}-\gamma$ & 13 & [8-35] & 13 & [8-22] & 0.74 & 0.51 \\
\hline Wk 4 & IL-6 & 10 & {$[4-25]$} & 4 & {$[3-11]$} & $<10^{-2}$ & 0.02 \\
\hline Wk 4 & IL-8 & 28 & [19-50] & 13 & [3-25] & $<10^{-2}$ & 0.02 \\
\hline Wk 4 & TNF- $\alpha$ & 43 & [27-75] & 25 & [15-41] & $<10^{-2}$ & 0.02 \\
\hline Wk 4 & $\mid \mathrm{P}-10$ & 3226 & [2078-6265] & 1834 & [1176-3567] & $<10^{-2}$ & 0.03 \\
\hline Wk 4 & IL-7 & 5 & [3-10] & 4 & [2-7] & 0.32 & 0.27 \\
\hline Wk 4 & $\mathrm{sCD} 25$ & 253 & [71-784] & 53 & [38-141] & $<10^{-2}$ & 0.02 \\
\hline Wk 4 & IFN- $\gamma$ & 27 & [11-34] & 12 & [8-27] & 0.08 & 0.11 \\
\hline
\end{tabular}

Table 2: List of biomarkers that were increased in patients with TB-IRIS

\section{ANRS 129 BKVIR-CYTOK study}

The median and interquartile range (IQR) of biomarker concentrations that were increased in TB-IRIS patients are reported for the wkO (ART initiation) and wk4 time points. Concentrations are reported in $\mathrm{pg} / \mathrm{ml}$. P values obtained by comparing biomarker concentrations between the IRIS+ and IRIS- groups are reported before (raw P values) and after (adaptive FDR P values) adjustment for multiple comparisons. Significant $P$ values $(P<0.05)$ are reported in bold type. 


\section{A: Factors that predict IRIS occurrence}

Cox proportional hazard model of time to IRIS occurence

\begin{tabular}{lccc}
\hline \multirow{2}{*}{ Explanatory variables } & \multicolumn{3}{c}{ Final multivariable model } \\
\cline { 2 - 4 } IL-7 level at wk0 (per additional log10 pg/ml) & HR & $95 \% \mathrm{Cl}$ & P-value $^{*}$ \\
sCD25 level at wk0 (per additional log10 FI) & 5.03 & $(1.26 ; 20.00)$ & $\mathbf{0 . 0 2 2}$ \\
IP-10 level at wk0 (per additional 1000 FI) & 4.76 & $(1.59 ; 14.30)$ & $\mathbf{0 . 0 0 5}$ \\
Hemoglobin (per additional g/dL) & NA & NA & NA \\
BMI (per additional $\left.\mathrm{kg} / \mathrm{m}^{<}\right)$ & NA & NA & NA \\
\hline
\end{tabular}

Logistic regression model of IRIS occurrence

\begin{tabular}{lccc}
\hline Explanatory variables & \multicolumn{3}{c}{ Final multivariable model } \\
\cline { 2 - 4 } IL-7 level at wk0 (per additional log10 pg/ml) & OR & $95 \% \mathrm{Cl}$ & P-value* $^{*}$ \\
sCD25 level at wk0 (per additional log10 FI) & 7.07 & $(1.12 ; 44.80)$ & $\mathbf{0 . 0 3 8}$ \\
IP-10 level at wk0 (per additional $1000 \mathrm{FI})$ & 6.12 & $(1.19 ; 31.40)$ & $\mathbf{0 . 0 3 0}$ \\
Hemoglobin (per additional g/dL) & NA & NA & NA \\
BMI (per additional $\left.\mathrm{kg} / \mathrm{m}^{<}\right)$ & NA & NA & NA \\
\hline
\end{tabular}

\section{B: Factors that predict levels of inflammatory cytokines at wk4}

Multiple linear regression model of IL-6 $(\log 10 \mathrm{FI})$ at wk4

\begin{tabular}{|c|c|c|c|}
\hline Explanatory variables & Beta & $95 \% \mathrm{Cl}$ & P-value* \\
\hline Intercept & 1.98 & $(0.68 ; 3.28)$ & 0.003 \\
\hline IL-7 level at wk0 (per additional $\log 10$ pg/ml) & 0.26 & $(0.02 ; 0.50)$ & 0.033 \\
\hline sCD25 level at wk0 (per additional log10 FI) & 0.03 & $(-0.18 ; 0.25)$ & 0.758 \\
\hline Hemoglobin at wk0 (per additional g/dL) & -0.07 & $(-0.13 ;-0.02)$ & 0.015 \\
\hline BMI at wk0 (per additional kg/m2) & -0.01 & $(-0.04 ; 0.01)$ & 0.264 \\
\hline \multicolumn{4}{|c|}{ Multiple linear regression model of IL-8 $(\log 10 \mathrm{FI})$ at wk4 } \\
\hline Explanatory variables & Beta & $95 \% \mathrm{Cl}$ & P-value* \\
\hline Intercept & 2.54 & $(1.36 ; 3.73)$ & $<0.001$ \\
\hline IL-7 level at wk0 (per additional log10 pg/ml) & 0.32 & $(0.10 ; 0.53)$ & 0.005 \\
\hline sCD25 level at wk0 (per additional log10 FI) & -0.02 & $(-0.22 ; 0.18)$ & 0.835 \\
\hline Hemoglobin at wk0 (per additional g/dL) & -0.06 & $(-0.11 ; 0.00)$ & 0.036 \\
\hline BMl at wk0 (per additional kg/m2) & -0.02 & $(-0.04 ; 0.00)$ & 0.119 \\
\hline \multicolumn{4}{|c|}{ Multiple linear regression model of TNF- $\alpha(\log 10 \mathrm{FI})$ at wk4 } \\
\hline Explanatory variables & Beta & $95 \% \mathrm{Cl}$ & P-value* \\
\hline Intercept & 2.31 & $(1.24 ; 3.38)$ & $<0.001$ \\
\hline IL-7 level at wk0 (per additional $\log 10$ pg/ml) & 0.31 & $(0.12 ; 0.51)$ & 0.002 \\
\hline sCD25 level at wk0 (per additional log10 FI) & 0.07 & $(-0.11 ; 0.25)$ & 0.444 \\
\hline Hemoglobin at wk0 (per additional g/dL) & -0.05 & $(-0.1 ; 0.00)$ & 0.044 \\
\hline BMI at wk0 (per additional kg/m2) & -0.01 & $(-0.03 ; 0.00)$ & 0.129 \\
\hline
\end{tabular}

Table 3: Baseline variables associated with IRIS occurence (A) and with inflammatory cytokines at wk 4 (B) ANRS 129 BKVIR-CYTOK study

(A): Logistic and Cox regression models were applied to determine whether a panel of 3 biomarkers chosen on a pathophysiologic basis (IL-7; IP-10; sCD25) at wk0 allowed to predict the occurrence of IRIS. Final multivariable models were obtained after step-wise backward selection procedure. Both models show that baseline sCD25 and IL-7 are independent predictors of IRIS occurrence.

The Cox proportional hazard model takes into account the time to IRIS occurrence, whereas the logistic model treats IRIS as a binary variable (occurrence of IRIS: yes or no). The hazard ratios (odds ratio in the logistic model) for the risk (odds in the logistic model) of developing IRIS per unit increase in the explanatory variables (measured at $\mathrm{wk} 0$ ) are reported.

(B) Multiple linear regression models were used to determine the variables predictive of the levels of three inflammatory biomarkers at wk4: IL-6, IL-8, and TNF- $\alpha$. The full multivariable models are shown (no step-wise variable selection procedure). The parameter beta reflects the mean estimated change in the dependent variable (the given cytokine at wk4) per unit of the explanatory variable (measured at wk0).

*: Raw $\mathrm{P}$ values are reported. Significant $\mathrm{P}$ values are reported in bold. HR: hazard ratio. OR: odds ratio. Cl: confidence interval. NA: not applicable.

FI: fluorescence intensity. wk: week. 

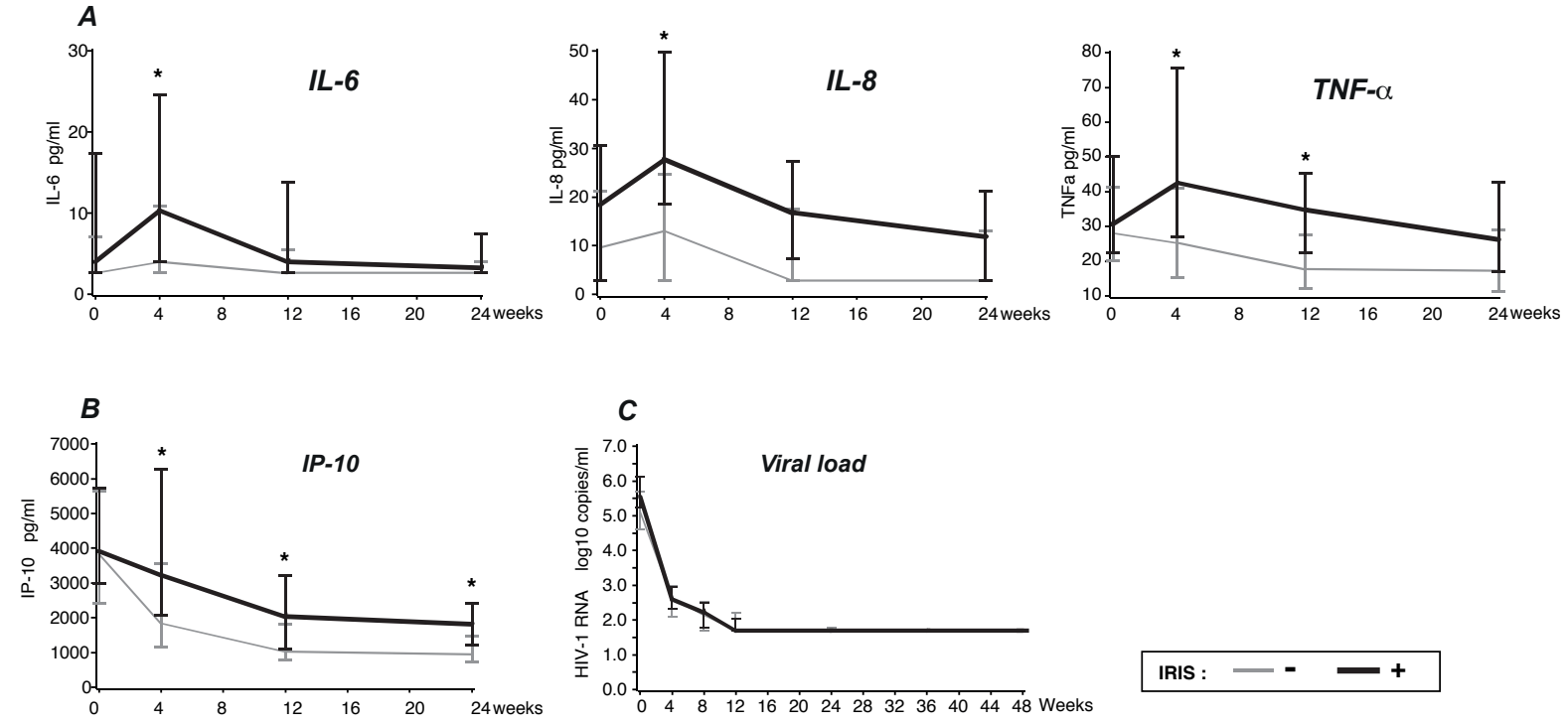

IRIS : $=-\quad+$

$\begin{array}{ll}\text { Figure 1: } & \text { Induction of inflammatory mediators during IRIS } \\ \text { ANRS } 129 \text { BKVIR-CYTOK study }\end{array}$ 
A: IL-7

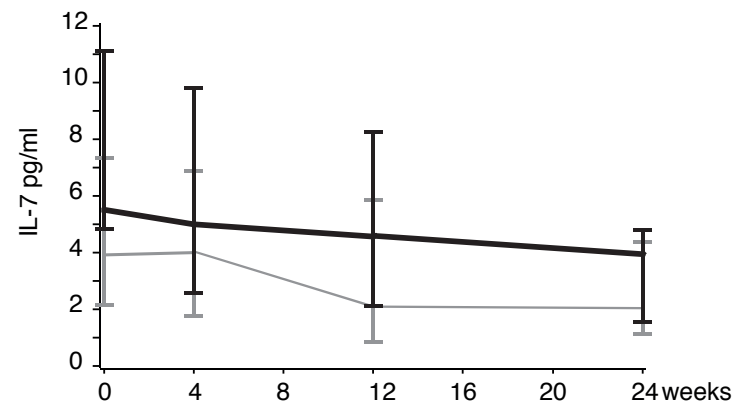

C: $s C D 25$

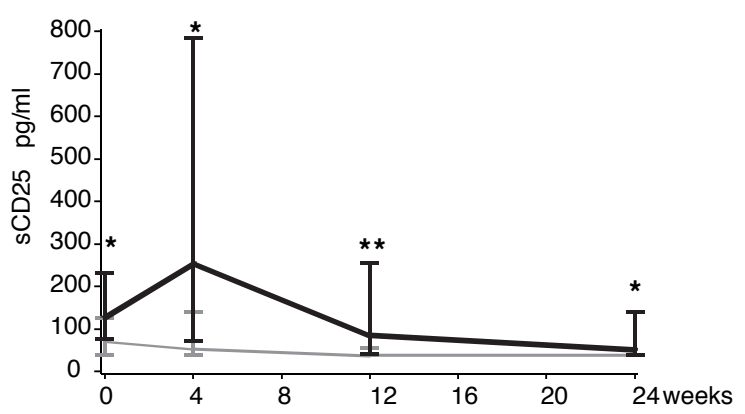

B: CD4 counts

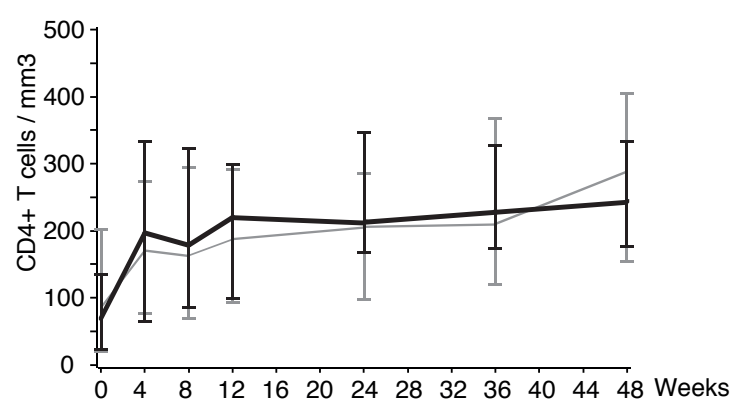

Figure 2: Induction of CD4+ T cell activation markers before and during TB-IRIS ANRS 129 BKVIR-CYTOK study 


\begin{tabular}{lccc}
\hline Explanatory variables & \multicolumn{3}{c}{ Univariable models } \\
\cline { 2 - 4 } IL-7 level at wk0 (per additional log10 pg/ml) & HR & $95 \% \mathrm{Cl}$ & P-value $^{*}$ \\
SCD25 level at wk0 (per additional log10 FI) & 3.69 & $(0.97 ; 14.00)$ & 0.055 \\
IP-10 level at wk0 (per additional 1000 FI) & 3.40 & $(1.28 ; 9.05)$ & $\mathbf{0 . 0 1 4}$ \\
Hemoglobin (per additional g/dL) & 1.06 & $(0.90 ; 1.23)$ & 0.495 \\
BMI (per additional $\left.\mathrm{kg} / \mathrm{m}^{<}\right)$ & 0.78 & $(0.58 ; 1.04)$ & 0.095 \\
\hline
\end{tabular}

\section{Logistic regression models of IRIS occurrence}

\begin{tabular}{lccc}
\hline Explanatory variables & \multicolumn{3}{c}{ Univariable models } \\
\cline { 2 - 4 } IL-7 level at wk0 (per additional log10 pg/ml) & OR & $95 \% \mathrm{Cl}$ & $\mathrm{P}_{\text {-value }}$ \\
sCD25 level at wk0 (per additional log10 FI) & 5.57 & $(1.03 ; 30.10)$ & $\mathbf{0 . 0 4 6}$ \\
IP-10 level at wk0 (per additional 1000 FI) & 4.75 & $(1.13 ; 19.90)$ & $\mathbf{0 . 0 3 3}$ \\
Hemoglobin (per additional g/dL) & 1.07 & $(0.87 ; 1.31)$ & 0.517 \\
BMI (per additional kg/m) & 0.71 & $(0.50 ; 0.99)$ & $\mathbf{0 . 0 4 7}$ \\
\hline
\end{tabular}

\section{Supplementary Table 1: Baseline variables associated with IRIS occurrence . Univariable models} ANRS 129 BKVIR-CYTOK study

(A): Logistic and Cox regression models were applied to determine whether a panel of 3 biomarkers chosen on a pathophysiologic basis (IL-7; IP-10; sCD25) at wk0 allowed to predict the occurrence of IRIS. The initial univariable models are reported in this table.

The Cox proportional hazard model takes into account the time to IRIS occurrence, whereas the logistic model treats IRIS as a binary variable (occurrence of IRIS: yes or no). The hazard ratios (odds ratio in the logistic model) for the risk (odds in the logistic model) of developing IRIS per unit increase in the explanatory variables (measured at wk0) are reported.

*: Raw $\mathrm{P}$ values are reported. Significant $\mathrm{P}$ values are reported in bold. HR: hazard ratio. OR: odds ratio. $\mathrm{Cl}$ : confidence interval. NA: not applicable. FI: fluorescence intensity. wk: week. 


\section{Supplementary File 1:}

\section{ANRS 129 BKVIR TRIAL GROUP}

\section{Investigator Sites:}

Saint-Jean hospital, Perpignan: H. Aumaître, F. Borsato, M. Malet, M. Médus, L. Moreau, S. Neuville, M. Saada. Avicenne hospital, Bobigny: S. Abgrall, D. Ahoudji, L. Balmard, M. Bentata, O. Bouchaud, A. Boudribila, J. Cailhol, R. Dhote, R. Djebbar, H. Gros, P. Honoré, T. Huynh, A. Krivitzky, R. Mansouri, C. Pizzocolo, F. Rouges, E. Viot. Villeneuve SaintGeorges hospital: B. Amar, J. Bantsimba, S. Dellion, O. Patey, L. Richier. Pellegrin hospital, Bordeaux: M. Dupon, H. Dutronc, D. Neau, JM. Ragnaud, I. Raymond. Necker hospital, Paris: S. Boucly, L. Gaichoustet, O. Lortholary, A. Maignan, F. Touam, JP. Viard. Lariboisière hospital, Paris: JF. Bergmann, E. Boulanger, V. Delcey, M. Diemer, A. Durel, F. Jouade, M. Parrinello, A. Rami, P. Sellier. Saint-Germain en Laye hospital: P. Brazille, C. Leclerc, Y. Welker. Raymond Poincaré hospital, Garches: L. Bernard, H. Berthé, C. Perronne, J. Salomon, P. de Truchis. Paul Brousse hospital, Villejuif: C. Bolliot, C. Couzigou, O. Derradji, L. Escaut, E. Teicher, D. Vittecoq. Tenon hospital, Paris: C. Chakvetadze, C. Fontaine, T. L'Yavanc, A. Maresca, G. Pialoux, L. Slama, L. Tuna. Antoine Béclère hospital, Clamart: D. Bornarel, F. Boué, A. Chassaing, L. Chaiba-Berroukeche, V. Chambrin, AM. Delavalle, P. Galanaud, A. Levy, C. Pignon. Bichat Claude-Bernard hospital, Paris: D. Bonnet, JL. Ecobichon, I. Fournier, G. Fraquiero, J. Gerbe, A. Gervais, V. Guiyedi, L. Iordache, V. Joly, P. Klutse, JJ. Laurichesse, C. Leport, M. Onanga, G. Pahlaval, BC. Phung, P. Ralaimazava, P. Yeni. Cochin hospital, Paris: F. Almasi, M. Basler, N. Benammar, A. Brunes, C. Guérin, L. Guillevin, R. Meddour, D. Salmon, G. Spiridon, T. Tahi. Louis Mourier hospital, Colombes: M. Bloch, C. Ferreira, I. Mahe, V. Manceron, C. Minozzi, E. Mortier, AM. Simonpoli, P. Vinceneux, F. Zeng Ai. Henri Mondor hospital, Créteil: C. Chesnel, S. Dominguez, P. Jouve, AS. Lascaux-Cametz, JD. Lelièvre, Y. Levy, G. Melica, A. Sobel. Pitié Salpêtrière hospital, Paris: N. Bentaleb, A. Blondin-Diop, M. Bonmarchand, P. Bossi, C. Brancon, G. Breton, F. Bricaire, F. Caby, A. Canestri, C. Clavel, N. Edeb, S. Herson, M. Iguertsira, C. Katlama, H. Kouadio, P. Lagarde, JL. Lopez, F. Marguet, V. Martinez, H. Remidi, A. Simon, JF. Souchon, MA. Valantin. Saint-Antoine hospital, Paris: D. Bollens, PM. Girard, JL. Lagneau, B. Lefebvre, R. Mouchotte, Z. Ouazene, M. Sebire, A. Theveny-Christiany, N. Valin. Saint Louis hospital, Paris: A. Bourgarit, N. de Castro, J. Delgado, S. Ferret, C. Lascoux-Combe, JM. Molina, S. Parlier, J. Pavie, C. Pintado, D. Ponscarme, A. Rachline, D. Sereni, O. Taulera, C. de Verdiere, F. 
Vincent. Saint André hospital, Bordeaux: N. Bernard, M. Bonarek, F. Bonnet, J. Delaune, D. Lacoste, I. Louis, D. Malvy, P. Mercier, P. Morlat, MC. Pertusa, M. Schottey. Gui de Chauliac hospital, Montpellier: N. Chanteloube, A. Eden, V. Le Moing, A. Makilson, C. Merle de Boever, J. Reynes, C. Turrière, C. Tramoni, M. Vidal. Hôtel Dieu hospital, Nantes: C. Anavena, E. Billaud, C. Biron, B. Bonnet, J. Bouchez, D. Boutoille, D. Brosseau, C. Brunct, M. Colas, N. Feuillebois, H. Hüe, E. Launay, P. Morineau le Houssine, F. Raffi, V. Reliquet. L'Archet I hospital, Nice: E. Cua, P. Dellamonica, J. Durant, V. Rahelinirina. Pontchaillou hospital, Rennes: C. Arvieux, JM. Chapplain, F. Fily, E. Labbay, C. Michelet, F. Morin, C. Peaucelle, M. Revest, M. Ratajczak, F. Souala, P. Tattevin, R. Thomas. Purpan hospital, Toulouse: M. Alvarez, F. Balsarin, E. Bonnet, F. Busato, L. Cuzin, D. Marche, B. Marchou, P. Massip, M. Obadia, L. Porte. Gustave Dron hospital, Tourcoing: E. Aissi, F. Ajana, I. Alcaraz, V. Baclet, S. Dubus, Y. Gérard, H. Guerroumi, T. Huleux, A. Lahouste, MC. Marien, H. Melliez, Y. Mouton, MP. Pennel, M. Valette, N. Viget, Y. Yazdanpanah. De Brabois hospital, Nancy: S. Bevilacqua, L. Boyer, T. Lecompte, L. Letranchant, T. May, C. Rabaud, L. Thomas, R. Vancon, S. Wassoumbou. Charles Nicolle hospital, Rouen: P. Abboud, F. Borsa-Lebas, F. Caron, Y. Debab, M. Etienne, M. Faucon, I. Gueit. Nord hospital, Marseille: P. Brouqui, S. Mokhtari, J. Moreau, M. Schlojsers, E. Vandergheynst. Créteil hospital: M. Chousterman, I. Delacroix-Szmania, B. El Harrar, V. Garrait, S. Joannes, I. Luquet-Besson, M. Mouchet, L. Richier. Ambroise Paré hospital, Boulogne: A. Blase Stevens, C. Dupont, A. Freire Maresca, S. Greffe, T. Hanslik, B. Landi, J. Leporrier, E. Rouveix, K. Toth. Delafontaine hospital, Saint-Denis: L. El Mansouf, MA. Khuong-Josses, D. Méchali, J. Phalip Le Besnerais, B. Taverne. Jean Verdier hospital, Bondy: F. Barclay, O. Fain, G. Flexor, J. Stirnemann, S. Tassi. Chambéry hospital: M. Levast, O. Rogeaux, D. Raffenot, J. Tous.

Steering Committee: O. Lortholary, O. Bouchaud, ML. Chaix, G. Chêne, S. CouffinCadiergues, M. Dupon, C. Fagard, V. Joly, O. Launay, JM. Molina, J. Robert, C. Roussillon, C. Rouzioux, M. Tod, Y. Yazdanpanah.

Events Review Committee: O. Lortholary, G. Breton, E. Caumes, T. May, C. Roussillon, N. Veziris.

Clinical Trials Unit/ INSERM U897, Bordeaux School of Public Health (ISPED), University Bordeaux Segalen: M. Badets, C. Boucherie, C. Fagard, G. Chêne, C. Roussillon, N. Terras 


\section{ANRS 129 BKVIR-CYTOK STUDY GROUP}

O. Lortholary, O. Bouchaud, ML. Chaix, G. Chêne, S. Couffin-Cadiergues, M. Dupon, C. Fagard, V. Joly, O. Launay, JM. Molina, J. Robert, C. Roussillon, C. Rouzioux, M. Tod, Y. Yazdanpanah., M. Badets, C. Boucherie, C. Fagard, G. Chêne, C. Roussillon, N. Terras. 